\title{
Cytostatic Effects of Methanolic Extracts of Amsonia orientalis Decne. on MCF-7 and DU145 Cancer Cell Lines
}

\author{
Arda ACEMİ ${ }^{1}$, Gokhan DURUKSU², Fazıl ÖZEN ${ }^{1}$ \\ ${ }^{1}$ Kocaeli University, Faculty of Sciences and Arts, Department of Biology, 41380 Kocaeli, \\ Turkey; arda.acemi@kocaeli.edu.tr;fazil.ozen@kocaeli.edu.tr \\ ${ }^{2}$ Kocaeli University, Institute of Health Sciences, Center for Stem Cell and Gene Therapies Research and Practice, \\ Department of Stem Cell, 41380 Kocaeli, Turkey; gokhan.duruksu@kocaeli.edu.tr ( ${ }^{*}$ corresponding author)
}

\begin{abstract}
Amsonia orientalis is an ornamental plant with anti-cancer properties. To characterize the anti-cancer potential of the species, methanolic extracts were prepared from leaf and stem tissues of field-grown individuals. Also, a mixture of stems, leaves and roots of in vitro grown plantlets (SLR) were extracted with methanol and used. Effects of these extracts on the cancer cell lines MCF-7 (breast) and DU145 (prostate) were investigated. After incubation for $48 \mathrm{~h}$, the leaf extract gave the lowest $\mathrm{IC}_{50}$ values $\left(197.8 \mu \mathrm{M}\right.$ for MCF-7 and $300.9 \mu \mathrm{M}$ for DU145). The SLR extract also gave the similar results, but with higher IC $\mathrm{C}_{50}$ values. The stem extract had the weakest effect on cancer-cell-specific cytotoxicity. The extracts did not have a significant effect on DU145, compared to fibroblasts. The leaf extract increased the number of active-Caspase-3 positive cells in MCF-7 culture slightly, but the main effect of all extracts was on the cell proliferation rather than apoptosis. Real-time cellular analysis of MCF-7 demonstrated a 1.8-fold increase of doubling time for the leaf extract. The expression of proliferation-related gene MCM2 was found to be decreased in MCF-7 cells treated with the leaf extract, while its expression increased in fibroblasts after the same treatment. In conclusion, the extracts affected the MCF-7 cells at moderate concentrations. This study suggests that the leaf methanolic extracts might be a good source of compounds with cytostatical properties.
\end{abstract}

Keywords: apoptosis, caspase-3 staining, cytotoxicity, growth inhibition, Rhazya orientalis

\section{Introduction}

Plants have been used for their pharmacological properties since ancient times. Some of them are known for their healing activities and have been used to treat various diseases. As being a dicotyledonous plant family, Apocynaceae contains not only plants with ornamental merit but also prominent species like Catharanthus roseus which is classically known for its monoterpenoid indole alkaloids with therapeutic utilities, such as vincristine and vinblastine used in cancer chemotherapy (Van der Heijden et al., 2004). Also, there are various reports about anti-cancer activities of several other species of Apocynaceae (Fouche et al., 2006; Wong et al., 2011a; Calderón-Montaño et al., 2013). Apart from the other commonly known genera in this family, the genus Amsonia Walter consists of species with both ornamental and medicinal potentials which occur in a wide range of habitats throughout central, southern and eastern North America. However, some of them are native to southern Europe, Turkey, Japan, Korea and China. One of these species is Amsonia orientalis Decne. (syn. Rhazya orientalis (Decne.) A. DC.) which has natural distribution in northwest Turkey and northeast Greece (Acemi et al., 2016). Also, it is cultivated for ornamental purposes in Europe and United States. In a study conducted to reveal the plant's medicinal properties, it was reported that $A$. orientalis has a strong antimicrobial activity on several yeasts and bacteria (Akyalçın et al., 2006). Furthermore, six new flavonoid glycosides and indole alkaloids such as Tabersonine, Secamine and Picralinal which are known for their anti-cancer and anti-tumor activities were isolated from the plant over the last decades (Rahman et al., 1989; Itoh et al., 2002). Also, in vitro propagation studies on the plant were conducted recently, and an effective method was developed using nodal explants as starting tissues for in vitro cultures (Acemi et al., 2013a; 2013b). Since $A$. orientalis has a rhizomatous root system in nature, over-collection of the plant for medicinal and/or ornamental purposes would harm the natural distribution of the plant. Therefore, in vitro propagated plants would supply biomass for pharmaceutical and horticultural industry.

Cell cycle modulation by various natural and synthetic agents attracts widespread attention to limit the development of cancer cells. Because of its chemotherapeutic phytochemical content, extracts of $A$. orientalis should inhibit the proliferation of selected cancer cell lines. Although the plant has high medicinal importance, there is no report in the literature 
regarding the in vitro anti-cancer activity of $A$. orientalis extracts. The present study aims to investigate in vitro effects of methanolic extracts of $A$. orientalis on the cancer cell lines MCF-7 and DU145. Analysis of the extracts from different anatomical parts of the plant was performed on these two cancer cell lines to understand the anti-carcinogenic potential of the plant.

\section{Materials and Methods}

Plant material collection and preparation for extraction and in vitropropagation processes

Tissue samples of Amsonia orientalis were collected from its wild population located in Gaziosmanpaşa district of Balkkesir province of Turkey. The voucher specimens (no: 18138) were deposited in the herbarium of Uludağ University (BULU). The aerial parts of the field-grown individuals and whole plant extract were planned to use in the experiments. In order to minimize the harm to this rhizomatous plant's natural vegetation, root samples were not collected from the individuals in nature. Therefore, the extract from in vitro propagated plantlets was employed in the experiments instead of whole plant extract. The leaves and shoots of field-grown individuals collected for extraction process were cut into 3-4 cm long pieces and dried under the sun. Some of the shortened shoots, $1-2 \mathrm{~cm}$ in length, with at least one node (explants) were selected to establish in vitro cultures.

\section{In vitro generation of plant material}

Explants were cultured in Murashige \& Skoog's (MS) (1962) medium (Duchefa, Haarlem, Netherlands) supplemented with $1.0 \mathrm{mg}^{1-1}$ 6-benzylaminopurine (BAP) according to the previous report (Acemi et al., 2013a). Cultures were incubated at $23 \pm 1{ }^{\circ} \mathrm{C}$ in a plant growth chamber with a $16 / 8 \mathrm{~h}$ light/dark photoperiod under $80 \mu \mathrm{mol} \mathrm{m} \mathrm{m}^{-2} \mathrm{~s}^{-1}$ photosynthetic photon flux density provided by cool-white fluorescent lights. After 4 weeks, explants were subcultured in the same fresh medium until desired quantity of plant material was reached. Excised shoots were rooted in MS medium supplemented with $1.0 \mathrm{mg} \mathrm{l}^{-1}$ indole-3-acetic acid (IAA). After 4 weeks of incubation, plantlets were removed from vessels and agar residues on roots were cleaned by washing with tap water. After all, these plantlets were dried under the sun. Extract prepared from in vitro propagated plantlets was named SLR (whole plant extract including stems, leaves and roots).

\section{Extraction procedure}

Samples were powdered in a porcelain mortar, and $5 \mathrm{~g}$ of each sample were extracted via Soxhlet apparatus for $24 \mathrm{~h}$ in $100 \mathrm{ml}$ of 80\% (v : v) aqueous methanol (Sigma-Aldrich, St. Louis, Mo, USA). Extracts were taken to dryness via rotary evaporator at $40{ }^{\circ} \mathrm{C}$ under vacuum. Remaining residues were collected and weighed. Samples were prepared by dissolving in dimethyl sulfoxide (DMSO) at the concentration of $100 \mathrm{mg} \mathrm{ml}^{-1}$ overnight at $4{ }^{\circ} \mathrm{C}$ and immediately stored at $-80^{\circ} \mathrm{C}$ until the assays were performed.

\section{Cells lines and culture}

Two cancer cell lines, MCF-7 (human breast adenocarcinoma cell line) and DU145 (androgen-independent human prostate cancer cell line), were used to test the anti-cancer effects of the extracts. Fibroblasts isolated from foreskin tissue by explant culture were used as the control for cell cytotoxicity. All cell lines were maintained in the culture media DMEM/F12 (Gibco, Paisley, UK) with $2.5 \mathrm{mM} \mathrm{L}$-glutamine and $0.5 \mathrm{mM}$ sodium pyruvate supplemented with $10 \%$ fetal bovine serum (FBS; Gibco) and $1 \%$ Pencillin-Streptomycin solution (Pen/Strep; Gibco). Cells were cultured under standard culture conditions $\left(37^{\circ} \mathrm{C}, 5 \% \mathrm{CO}_{2}\right)$. The culture medium was refreshed every two days.

\section{Determination of cell viability}

Cells were cultured in 96-well culture plate with different concentrations of plant extracts $(0,20,50,80,100,200,500 \mu \mathrm{g}$ $\mathrm{ml}^{-1}$ ) in culture media. Five thousand cells/well incubated for $48 \mathrm{~h}$ under the standard culture conditions. The culture medium was refreshed with the medium including $10 \% \mathrm{Wst}-1$ reagent (Roche, Mannheim, Germany). After incubation for $2 \mathrm{~h}$, the absorbance at $450 \mathrm{~nm}$ was measured.

The changes in cell numbers were expressed in percentage.

\section{Real-time cellproliferation}

xCELLigence RTCA DP Analyzer (ACEA Bioscience, SanDiego, CA) was used to monitor the cell proliferation. Freshly harvested MCF-7 cells were plated at $12.5 \times 10^{3}$ cells/well in CIM-Plates-16 (ACEA Bioscience). Cell index values were monitored every $10 \mathrm{~min}$ for $50 \mathrm{~h}$. Normalized data are expressed as mean \pm SD. The population doubling time was calculated by the instrument's software provided with the device.

\section{Active Caspase-3 staining}

For active caspase-3 staining, cells were fixed in ice-cold methanol for $10 \mathrm{~min}$. After permeabilization with $0.025 \%$ Triton X-100 (Merck, Darmstadt, Germany), the cells were incubated with $1.5 \%$ blocking serum (Santa Cruz Biotechnology, Heidelberg, Germany) in phosphate suffer solution (PBS) for 30 min at $37^{\circ} \mathrm{C}$ and incubated overnight at $4{ }^{\circ} \mathrm{C}$ with the primary antibody (Millipore, Cat. No. AB3623). After the incubation with secondary antibody for $25 \mathrm{~min}$, the cells were mounted with mounting medium containing 4,6-diamidino-2-phenylindole (DAPI; Santa Cruz Biotechnology).

\section{Gene expression analysis}

The gene expressions of MCM2 (Mini-Chromosome Maintenance 2), TNIP1 (TNF $\alpha$-induced protein 3-interactingprotein 1), MMP1 (Matrix Metallopeptidase 1), VEGF (Vascular Endothelial Growth Factor) and NF- $k B$ (Nuclear Factor kappa B) proteins were analyzed. Total RNA was extracted by High Pure RNA Isolation Kit (Roche Applied Science, Mannheim, Germany), according to the manufacturer's instructions. After synthesis of single strand cDNA by Transcriptor High Fidelity cDNA Synthesis Kit (Roche), the gene expression levels were detected by LightCycler 480 DNA SYBR Green I Master (Roche) with gene-specific primers on LightCycler 480 real-time PCR instrument, according to the manufacturer's protocol. Melting curve analysis for determining the dissociation of PCR products was performed from $60{ }^{\circ} \mathrm{C}$ to $95^{\circ} \mathrm{C}$ to confirm the presence of a single peak. The list of primers and their sequence information were given in Table 1 .

\section{Statisticalanalysis}

$\mathrm{IC}_{50}$ values denote the concentration of the extract, which is required to decrease the cell number by half compared to the culture without any plant extracts. All the experiments were repeated at least three times and represented as means with standard deviations (SD). The significance of the results was 
Table 1. Primers used in Real-Time PCR analysis

\begin{tabular}{ccc}
\hline Gene & Primer Sequence & GeneBank Acc. No. \\
\hline $\begin{array}{c}\text { Minichromosome Maintenance } \\
\text { Complex Component 2 } \\
\text { (MCM2) }\end{array}$ & TTGGCGTGAGTTGCGTATTC & NM004526 \\
TNFAIP3 Interacting Protein 1 & GAGACTGAAAACGATTACAAACATC & NM001252385 \\
(TNIP1) & GTATTTGAGCAATATGCGGAAAGC & NM002421 \\
Metallopeptidase 1 & TCCTGAGATTTGAGAGACTCCAGTT 1$)$ & AY047581 \\
Vascular Endothelial Growth Factor & TTTTCAACTTGCCTCCCATC \\
(VEGF) & TGTGGTGTCTCACAGCTTCC & NM003998 \\
Nuclear Factor of kappa light \\
polypeptide gene enhancer in B-cells 1 \\
$(\mathrm{NF}$ B $)$
\end{tabular}

determined by SPSS 10.0 (Chicago, IL, USA). Data were analyzed using unpaired Student's t-test in conjunction with the NewmanKeuls test and analysis of variance for repeated measures where appropriate. Differences between the experimental and control groups were regarded as statistically significant when $p<0.05$.

\section{Results}

Shoots started to regenerate from nodes of the cultured explants within the first week of incubation period. At the end of the incubation period of third subculture, an adequate number of plantlets (more than 250 individuals) were being raised in vitro. In the rooting process, these plantlets started to response to the rooting medium after the first week of incubation period. Following the emergence of the first root, the root development showed an increase within the rest of incubation period. The rooting process succeeded in all of the cultured plantlets. Due to the high humidity in culture vessels, the plants taken outside lost their water gradually at room conditions. The sun-dried plantlets were then taken to the extraction process.

At low doses, all extracts supported the cell proliferation at different levels (Fig. 1). The leaf extract had the strongest effect on cancer cell numbers. At high concentration $\left(500 \mu \mathrm{g} \mathrm{ml}^{-1}\right)$ of leaf extract, all the cell numbers significantly decreased by almost $40 \%$ with respect to control medium. Nevertheless, cell proliferation significantly increased at low doses $\left(20 \mu \mathrm{g} \mathrm{ml}^{-1}\right)$. Effects of the high doses were not found to be cell-specific, but the response of MCF-7 to leaf extract was more severe than the responses given to stem and SLR extract (Fig. 1A).

On the other hand, the stem extract had a lower effect on decrement of the cell viability and proliferation. The reduction of cell numbers was limited in this extract. Especially in MCF7, the lower doses of stem extract improved the quantity of cells (Fig. 1B). The SLR extract showed the similar dose-response pattern as the leaf extract, but the reduction of cell number was weaker (Fig. 1C).

$\mathrm{IC}_{50}$ value of leaf extract $\left(197.8 \mu \mathrm{g} \mathrm{ml}^{-1}\right.$ for MCF-7; 300.9 $\mu \mathrm{g} \mathrm{ml}^{-1}$ for DU145) was found to be lower than the other extracts (Fig. 2).

The smaller quantity of leaf extract was required to reduce the number of MCF-7 cells compared to the stem and SLR extract (591.5 $\mathrm{g} \mathrm{ml}^{-1}$ and $306.5 \mathrm{~g} \mathrm{ml}^{-1}$, respectively). Noticeably, the extracts had also a detrimental effect on the viability of fibroblast cells. Compared to fibroblasts, the prostate cancer cell line DU145 was not affected significantly. The concentration of extract required to kill the DU145 cells (300.9 $\mathrm{g} \mathrm{mll}^{-1}$ for leaf; $519.8 \mu \mathrm{g} \mathrm{ml}^{-1}$ for stem; $437.4 \mu \mathrm{g} \mathrm{ml}^{-1}$ for
SLR) was as high as the concentration required for fibroblasts $\left(313.4 \mu \mathrm{g} \mathrm{ml}^{-1}\right.$ for leaf; $495.3 \mu \mathrm{g} \mathrm{ml}^{-1}$ for stem; $521.4 \mu \mathrm{g} \mathrm{ml}^{-1}$ for SLR). At this point, MCF-7 viability was strongly influenced by leaf $\left(197.8 \mu \mathrm{g} \mathrm{ml}^{-1}\right)$ and SLR (306.6 $\mathrm{g} \mathrm{ml}^{-1}$ ) extracts (Fig. 2). The stem extract was found to be less effective against MCF-7 compared to the other extracts while there was no significant difference observed between DU145 and fibroblasts in response to stem extract.

The apoptotic states of the MCF-7 and fibroblast cells were checked by immune staining against active (cleaved) Caspase-3. In general, the cells cultured in the medium with leaf extract were less in number and they also showed positive staining for active Caspase-3 (Fig. 3).

The faint staining by anti-Caspase- 3 in the cell cultures with the other extracts indicated the weak induction of apoptosis. The staining pattern which was in the periphery of the nuclei is more specific in the cultures treated with leaf extract. In the stem and SLR extract groups, cells showed a pale cytoplasmic staining, but not around the nucleus. The untreated culture medium (control group) did not show any specific staining (Fig. 3). The results showed that the plant extracts were significantly effective on MCF-7 cells. The cytotoxic effect of leaf extract was found to be higher and specific to breast cancer cell line.

The real-time proliferation of MCF-7 cells was monitored over $48 \mathrm{~h}$. The rate of proliferation significantly decreased in the culture treated with leaf extract, which confirmed the Wst1 data (Fig. 4A). During the culture, the viability of cells was not significantly affected, but the doubling time of MCF-7 was increased to $26.4 \pm 1.0 \mathrm{~h}$ in cultures with leaf extract compared to cells in the control group with DMSO $(14.7 \pm 1.1 \mathrm{~h})$. Cells in the media with stem and SLR extract had the doubling times of $19.9 \pm 2.4 \mathrm{~h}$ and $18.2 \pm 0.7 \mathrm{~h}$, respectively (Fig. $4 \mathrm{~B}$ ).

To explain the effects of investigated extracts on cell proliferation and apoptosis, the gene expressions of some key proteins were estimated by quantitative PCR (Fig. 5).

The expression of MCM2 protein, one of the replication regulatory proteins, altered differently in cultures when treated with the extracts used at their $\mathrm{IC}_{50}$ values for MCF-7 (Fig. 5B). MCM2 in fibroblasts (Fig. 5A) increased considerably in contrast to MCF-7, in which the expression was downregulated almost 10 times when cultured with leaf or stem extracts. Compared to the other extracts, the leaf extract acted differently on MCF-7 cells by increasing TNIP1 expression. At the same time, the NF- $\kappa \mathrm{B}$ expression was also increased in MCF-7 cells treated with leaf extract. Expressions of the important genes in migration and angiogenesis, MMP1 and VEGF increased in the cancer cells. The stem extract 

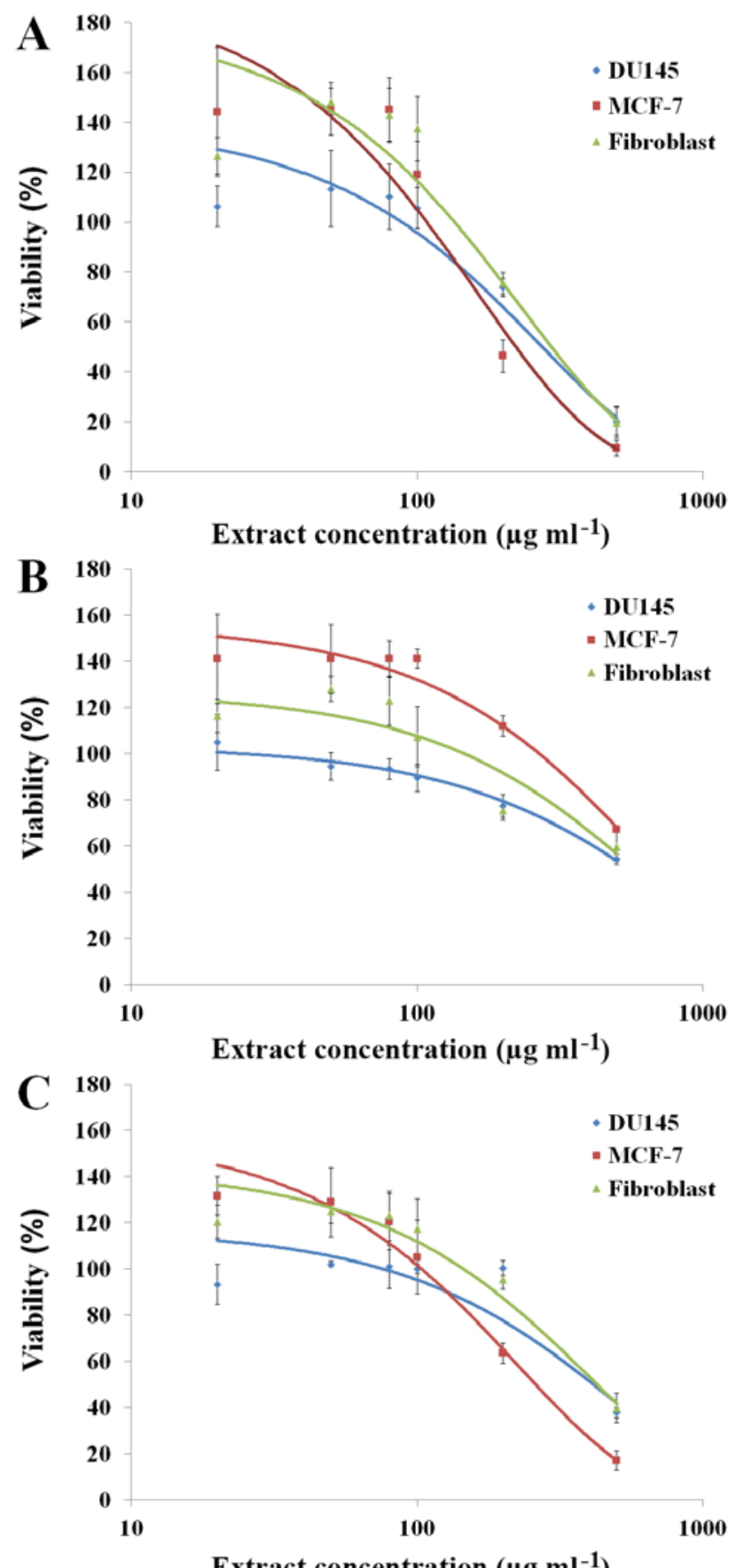

Fig. 1. Measurement of cell viability by WST-1 after $48 \mathrm{~h}$ of incubation with leaf (A), stem (B) and SLR extracts (C). The ratios of viable cells were estimated with respect to the cells cultured in the same media without plant extracts

weakly suppressed this expression, but the leaf extract increased their expression almost 9 and 5 times, respectively (Fig. 5B). The SLR extract suppressed the expression of MCM2, TNIP1 and $\mathrm{NF} \kappa \mathrm{B}$, and weakly induced the MMP1 and VEGF expressions in MCF-7 cells, compared to the cells cultured with the other extracts.

\section{Discussion}

In this study, MCF-7 (breast cancer) and DU145 (prostate cancer) cell lines were used to monitor the anti-cancer effect of

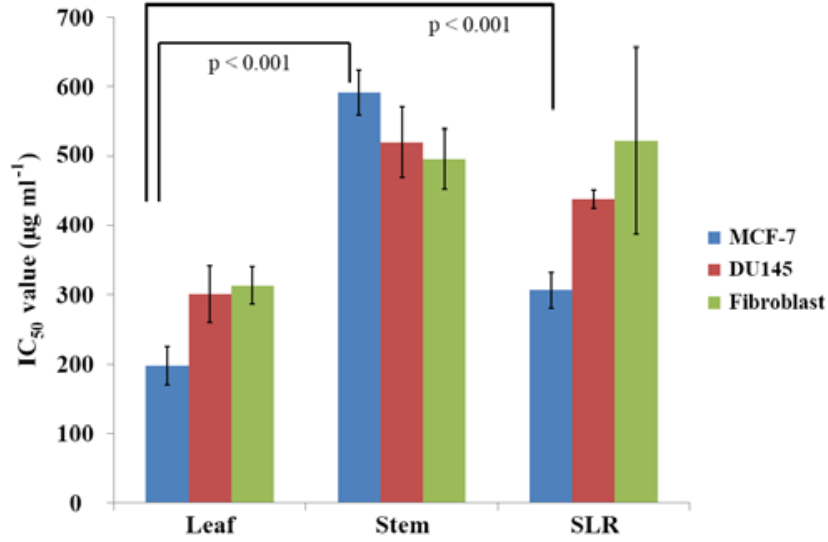

Fig. 2. Effects of methanolic extracts on the cytotoxicity of cancer cell lines (MCF-7 and DU145) and fibroblasts. The $\mathrm{IC}_{50}$ values were estimated by $\mathrm{LDH}$ assay after $48 \mathrm{~h}$ of incubation

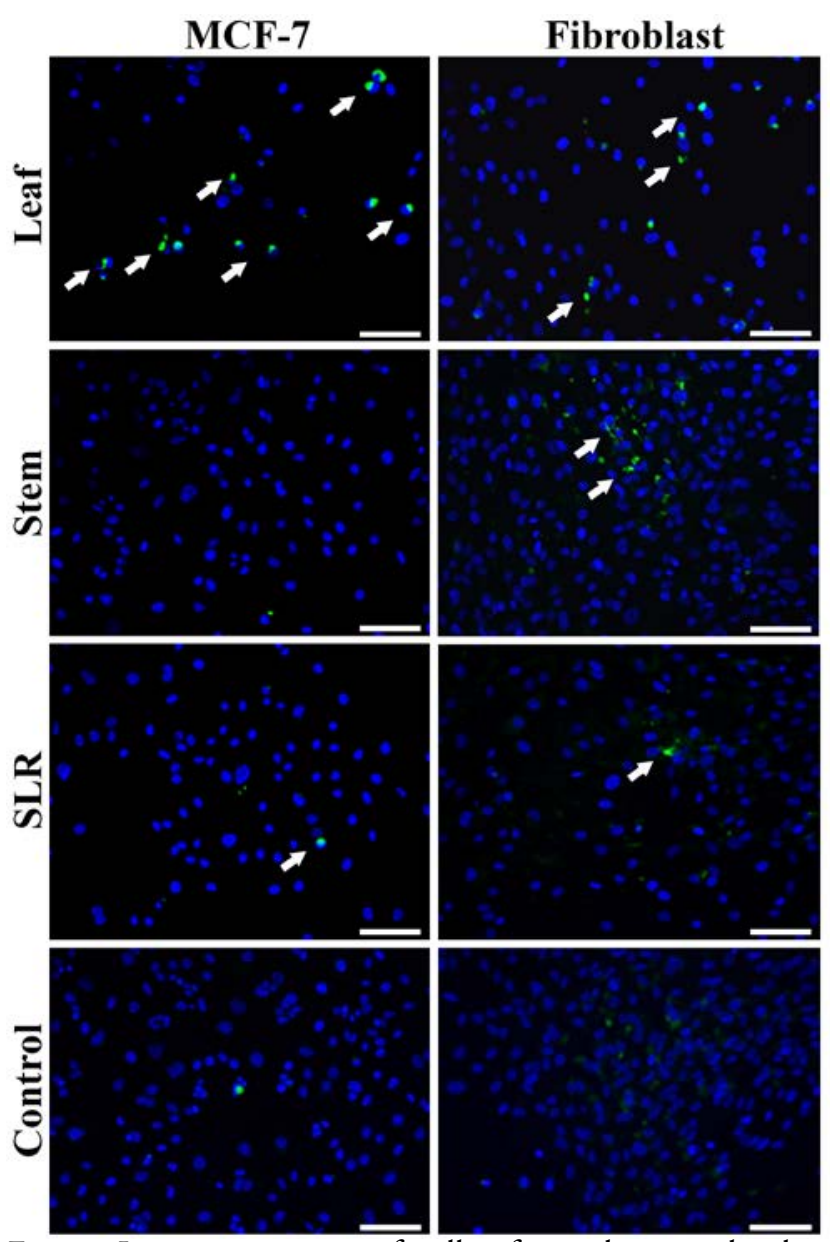

Fig. 3. Immune staining of cells after culture with plant extracts against active Caspase-3. Active-Caspase-3 staining (green), indicated by a white arrow, could be observed strongly in cytoplasm near the nucleus of MCF-7 cells treated with the leaf extract. The cell nuclei were stained with DAPI (blue). Scale bars: $100 \mu \mathrm{m}$

Amsonia orientalis extracts obtained from different anatomical parts of the plant. MCF-7 cell line is estrogen receptordependent and carries the wild-type tumor suppressor p53 gene whereas DU145 is androgen-insensitive prostate cancer 
40
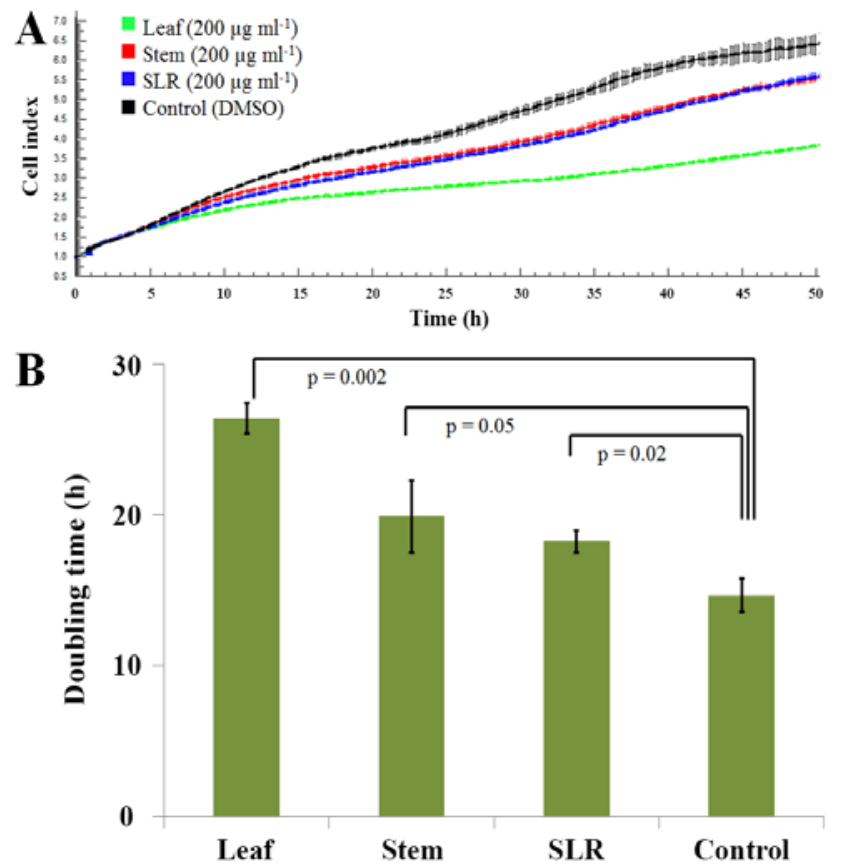

Fig. 4. The real-time monitoring of cell proliferation by the xCELLigence system. MCF-7 cells at a density of 12.500 cells/well were cultured in complete medium supplemented with different methanolic extracts or DMSO (control) for 48 $\mathrm{h}(\mathrm{A})$. The mean doubling time of MCF-7 cells was calculated by the instrument's software (B).

cell line which has moderate metastatic potential and does not express normal p53 gene (Bartek et al., 1990; Yaacob et al., 2010). The plant's extracts differently affected the cells. At higher concentrations, the cytotoxic effect was observed for all cell lines including fibroblasts. Therefore, the use of any crude extracts for cancer treatment without the proper isolation of bioactive components is not applicable. The leaf extract showed better activity in decreasing the number of viable MCF-7 cells than the stem extract. However, this cancerspecific action was limited only with MCF-7, and DU145 cells were not significantly affected compared with fibroblasts. On the other hand, the proliferation of MCF-7 and fibroblast cells was supported at low extract doses, but DU145 showed a limited response. It should be noted that the leaf and SLR extracts affected very similarly to the cell lines. SLR extracts were obtained from shoots, leaves and roots of the in vitro propagated plantlets, of which leaves constitute the major plant mass with low latex content. Plant latex is a rich source of pharmaceuticals and contains important biomolecules such as glycosides, flavonoids and saponins, which show biological activities against cancer cells (Upadhyay, 2011). The intermediary effect of the in vitro propagated plantlets might be attributed to the very low latex content. The real-time measurement of cell numbers indicated that SLR extract affected MCF-7 cells at the same degree as the stem extract, but weaker than the leaf extract. This might indicate that the latex might not be the only factor in this varied action. The stem extract is obviously not suitable to be used against the proliferation of cancer cells. The $\mathrm{IC}_{50}$ values of the leaf and SLR extracts revealed that the effective dose for cytotoxicity targeted toward cancer cells was significantly lower in MCF-7. DU145
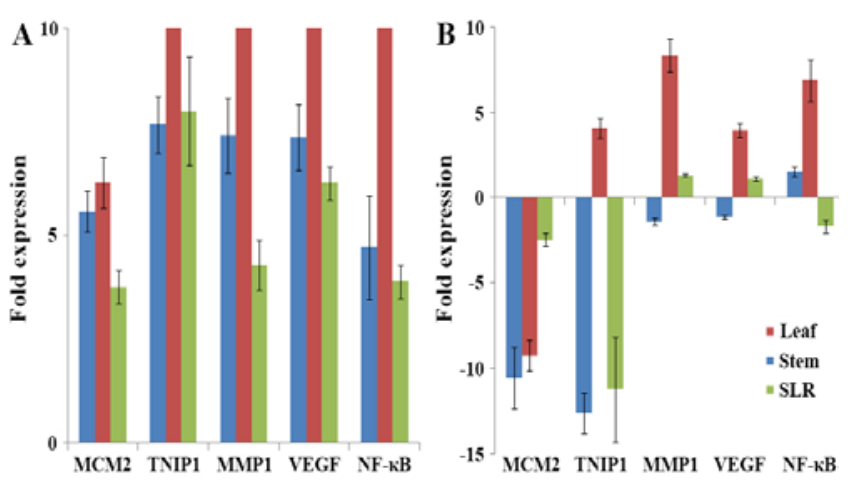

Fig. 5. Gene expression analyzes of fibroblast and MCF-7 cells by Real-Time PCR. After 48 h of culture with plant extracts, the expressions of MCM2 (proliferation), TNIP1 (antiapoptotic), MMP1 (migration), VEGF (migration) and NF$\kappa \mathrm{B}$ (proliferation) were analyzed for fibroblast (A) and MCF-7 (B). ActB gene expression was used as reference gene for normalization.

cells, however, were not affected cell-specifically. Formation and abundance of bioactive compounds in different anatomical parts of plants are influenced by their physiological activities and morpho-anatomical structures. Therefore, abovementioned difference between cell-type specificity of the tested extracts might be attributed to diversity among their secondary metabolite patterns, and modes of actions of these metabolites (Stanković et al., 2015). Besides, solvent selection plays an important role in extraction of these bioactive compounds. For example, total phenolic and flavonoid contents of different anatomical parts of Teucrium polium were found to be altered depending on the solvent used in extraction process (Stankovic et al., 2012). In a previous study, it was reported that ethanolic crude leaf extract of another Apocynaceae member, Alstonia scholaris, also showed inhibitory effect on proliferation of MCF-7 cells with an $\mathrm{IC}_{50}$ value of $29.76 \mu \mathrm{g} \mathrm{ml}^{-1}$ (Jagetia and Baliga, 2006). Another extraction was conducted with water and crude water extracts of Rheum officinale (Polygonaceae) inhibited the proliferation of MCF-7 cells with an IC 50 value of $515 \pm 10.1 \mathrm{~g} \mathrm{ml}^{-1}$ (Li et al, 2009). Furthermore, it has been reported that crude aqueous and methanolic extracts of Vernonia guineensis (Asteraceae) tuber demonstrates relatively weaker activity against DU145 cells, whereas dichloromethane extract is more potent with lower $\mathrm{IC}_{50}$ values (Toyang et al., 2012). Likewise, Wong et al. (2011b) stated that only DCM (dichloromethane : methanol) leaf extract of Catharanthus roseus showed activity against MCF-7 cells while hexane, methanol, DCM and dichloromethane extracts were all found to be cytostatic (anti-proliferative). Considering the results of our study and the mentioned studies above, it can be said that activities of $A$. orientalis extracts may be augmented using different solvents in the extraction process.

The expression of Caspase-3 was significantly higher in the MCF-7 culture treated with leaf extract, and it is visible in the cytoplasm close to the nucleus. This location of active Caspase3 staining could be explained by initial cytoplasmic activation of procaspase- 3 and translocation to the nucleus (Ramuz et al., 2003). The weak intensity and a low number of cells indicate that the Caspase-3-related apoptosis was not induced by the 
stem and SLR extracts, but slightly induced by the leaf extract. Activation of caspase is a central mechanism of apoptosis, and Caspase-3, $-6,-7$ are the key proteins in the execution phase of apoptosis (Vaux and Korsmeyer, 1999; Hunter et al., 2007; Li et al., 2010). The treatment with xanthone compound of Artocarpus obtusus revealed the activation of Caspase-8 and -9, but not Caspase-3 and -7 at low doses (Mohan et al., 2012). But the anti-cancer effect of this compound from the plant was explained by inhibition of NF- $k B$ in MCF-7. NF- $k B$ inhibits apoptosis and plays a key role in the mechanism of antiapoptosis of tumors (Yang et al., 2004). Suppression of NF- $k B$ expression induces apoptosis and limits the proliferation of cancer cells (Dalen and Neuzil, 2003). In our study, the NF- $\kappa$ B expression was suppressed critically in the SLR extract. This might indicate the anti-cancer effect of the extracts via mechanisms of NF-kB inhibition. However, the NF- $k B$ expression was up-regulated after the leaf extract treatment, although the number of viable MCF-7 cells sharply decreased. Considerable increment in expression of this apoptosis and inflammation-inducing protein (NF- $\mathrm{kB}$ ) in the MCF-7 cells might induce apoptosis despite increased TNIP1 expression which inhibits TNF-induced NF- $\mathrm{B}$ dependent gene expression and, this might have a role in the anti-cancer activity. The elevated level of TNIP1 protein could also act as antiapoptotic in fibroblasts, and protect them against apoptosis. The increased level of apoptotic cells in MCF-7 culture could also be explained by low-level TNIP1 expression. The increament in doubling time of MCF-7 could be explained by inactivation of NF- $\mathrm{kB}$ activity in all MCF-7 cells treated with the extracts. The decrease in the cell proliferation could be also associated with the expression of MCM2, which is one of the chromosome replication proteins, and directly associated with DNA replication. This expression was downregulated in all MCF-7 cells treated with the extracts. The expression of proproliferative factors (NF-kB and MCM2) and apoptosis inhibitors (TNIP1) were induced in fibroblast in the presence of the all tested extracts. The results were in parallel with other assays, which demonstrated the proliferating fibroblast cells with negligible Caspase-3 expression. The plant's methanolic extracts had the function as pro-proliferative and antiapoptotic on fibroblasts, whereas they acted totally opposite in MCF-7 cells.

NF- $\kappa \mathrm{B}$ could regulate not only apoptosis but also cell migration. The inhibition of NF- $k B$ decreased the activity of MMP-9 in MCF-7 cells (Pozo-Guisado et al., 2005). Considering that NF- $k \mathrm{~B}$ and MMP activities are involved in the control of cell migration. Also, all tested extracts adversely affected the actions of these compounds. The NF- $k \mathrm{~B}$ expression also decreased in parallel with the expressions of MMP1 and VEGF, which are critical proteins in cancer metastasis (Nakayama, 2013).

The selective cytotoxic effects of the extracts observed against the tested cancer cell lines may be hormone-dependent or -independent, $\mathrm{p} 53$-related or influenced by other properties of the cancer cell lines, although these characteristics are yet to be determined. In some cases, crude extracts have been reported to be more effective than standardized ones against cell proliferation or biochemical endpoints (Zhu et al., 2001).

\section{Conclusions}

The results of this study showed that Amsonia orientalis is capable to synthesize compounds that have the potentials to be used in cancer treatment. The production of compounds with apoptotic and cytostatic effects was more restricted to the leaves of the plant. The active compounds with anti-cancer properties can be produced more effectively via in vitro cell cultures. However, accumulation of these compounds would take time in in vitro cultures. In case of direct employment of the products from these cultures in extraction processes, some active compounds would not be accumulated at desired amounts. Thus, use of elicitors in cultures might enrich these compound contents of the cultured plants or a longer maturation period should be considered. Therefore, it is suggested that the in vitro propagated plant should be introduced to appropriate habitats and harvested following its maturation. Consequently, the methanolic crude extracts of $A$. orientalis were analyzed and they had the most significant impact on the breast cancer cell line, MCF-7. Further possible researches should be focused on the leaves of the plant for drug discovery. Nevertheless, the compounds with cytostatic or apoptotic activity are still needed to be separated and characterized exclusively from the leaves of the plant.

\section{Acknowledgements}

We would like to thank Cansu Subasi for her kind technical assistance in immune staining. For their kind help in the extraction process, we are grateful to Dr. Halim Aytekin Ergül and Serdar Aksan.

\section{References}

Acemi A, Türker-Kaya S, Özen F (2016). FT-IR spectroscopy based evaluation of changes in primary metabolites of Amsonia orientalis after in vitro 6-benzylaminopurine treatment. Notulae Botanicae Horti Agrobotanici Cluj-Napoca 44(1):209-214.

Acemi A, Özen F, Kran R (2013a). In vitro propagation of Amsonia orientalis Decne. from nodal segments of adult plants. Propagation of Ornamental Plants 13(1):25-32.

Acemi A, Kuran R, Özen F, Balcı S, Baydemir S, İlmaz Ç (2013b). Influence of medium composition on in vitro propagation of Amsonia orientalis Decne.Journal of Anatolian Natural Sciences 2:1-6.

Akyalçn H, Özen F, Dülger B (2006). Anatomy, morphology, palynology and antimicrobial activity of Amsonia orientalis Decne. (Apocynaceae) growing in Turkey. International Journal of Botany 2(1):93-99.

Bartek J, Iggo R, Gannon J, Lane DP (1990). Genetic and immunochemical analysis of mutant p53 in human breast cancer cell lines. Oncogene 5:893-899.

Calderón-Montaño JM, Burgos-Morón E, Orta ML, Mateos S, LópezLázaro M (2013). A hydroalcoholic extract from the leaves of Nerium oleander inhibits gycolysis and induces selective killing of lung cancer cells.Planta Medica79(12):1017-1023. 
42

Dalen H, Neuzil J (2003). Alpha-tocopheryl succinate sensitises a T lymphoma cell line to TRAIL-induced apoptosis by suppressing NFkappaB activation. British Journal of Cancer 88:153-8.

Fouche G, Khorombi E, Kolesnikova N, Maharaj VJ, Nthambeleni R, Van der Merwe M (2006). Investigation of South African plants for anticancer properties. Pharmacologyonline 3:494-500.

Hunter AM, LaCasse EC, Korneluk RG (2007). The inhibitors of apoptosis (IAPs) as cancer targets. Apoptosis 12:1543-68.

Itoh A, Kumashiro T, Tanahashi T, Nagakura N, Nishi T (2002). Flavonoid gycosides from Rhazya orientalis. Journal of Natural Products 65:352-357.

Jagetia GC, Baliga MS (2006). Evaluation of anticancer activity of the alkaloid fraction of Alstonia scholaris (Sapthaparna) in vitro and in vivo. Phytotherapy Research 20:103-109.

Li W-Y, Chan S-W, Guo D-J, Chung M-K, Leung T-Y, Yu P H-F (2009). Water extract of Rheum officinale Baill. induces apoptosis in human lung adenocarcinoma A549 and human breast cancer MCF-7 cell lines. Journal of Ethnopharmacology 124(2):251-256.

Li Z, Jo J, Jia JM, Lo SC, Whitcomb DJ, Jiao S, Cho K, Sheng M (2010). Caspase-3 activation via mitochondria is required for long-term depression and AMPA receptor internalization. Cell 141:859-71.

MohanS, AbdelwahabSI, Kamalidehghan B, Syam S, May KS, Harmal NS, ShafifiyazN, Hadi AH, Hashim NM, Rahmani M, Taha MM, Cheah SC, Zajmi A (2012). Involvement of NF- $\kappa \mathrm{B}$ and $\mathrm{Bc} 2 / \mathrm{Bax}$ signaling pathways in the apoptosis of MCF7 cells induced by a xanthone compound Pyranocycloartobiloxanthone A. Phytomedicine 19:10071015 .

Murashige T (1962), Skoog F. A revised medium for rapid growth and bioassays with tobacco tissue cultures. Physiologia Plantarum 15:473497.

Nakayama K (2013). cAMP-response element-binding protein (CREB) and NF- $\mathrm{B}$ B transcription factors are activated during prolonged hypoxia and cooperatively regulate the induction of matrix metalloproteinase MMP1. Journal of Biological Chemistry288:2258422595.

Pozo-Guisado E, Merino JM, Mulero-Navarro S, Lorenzo-Benayas MJ, Centeno F, Alvarez-Barrientos A, Fernandez-Salguero PM (2005). Resveratrol-induced apoptosis in MCF-7 human breast cancer cells involves a caspase-independent mechanism with downregulation of Bcl2 and NF-kappaB. International Journal of Cancer 115:7484.

Rahman AU, Qureshi MM, Zaman K, Malik S, Ali SS (1989). The alkaloids of Rhazya stricta and $R$ orientalis - a review. Fitoterapia 60(4):291-322.
Ramuz O, Isnardon D, Devilard E, Charafe-Jauffret E, Hassoun J, Birg F, Xerri L (2003). Constitutive nuclear localization and initial cytoplasmic apoptotic activation of endogenous caspase-3 evidenced by confocal microscopy. International Journal of Experimental Pathology 84:75-81.

Stanković MS, Mitrović TL, Matić IZ, Topuzović MD, Stamenković SM (2015). New values of Teucrium species: In vitro study of cytotoxic activities of secondary metabolites. Notulae Botanicae Horti Agrobotanici Cluj-Napoca 43(1):41-46.

Stankovic MS, Niciforovic N, Mihailovic V, Topuzovic M, Solujic S (2012). Antioxidant activity, total phenolic content and flavonoid concentrations of different plant parts of Teucrium polium L. subsp. Polium. ActaSocietatis Botanicorum Poloniae 81(2):117-122.

Toyang NJ, Wabo HK, Ateh EN, Davis H, Tane P, Kimbu SF, Sondengam LB, Bryant $J$ (2012). In vitro anti-prostate cancer and ex vivo antiangiogenic activity of Vernonia guineensis Benth. (Asteraceae) tuber extracts. Journal of Ethnopharmacology 141(3):866-871.

Upadhyay RK (2011). Plant latex: A natural source of pharmaceuticals and pesticides. International Journal of Green Pharmacy 5:169-180.

Van Der Heijden R, Jacobs DI, Snoeijer W, Hallard D, Verpoorte R(2004). The Catharanthus alkaloids: Pharmacognosy and biotechnology. Current Medicinal Chemistry 11:607-628.

Vaux DL, Korsmeyer SJ (1999). Cell death in development. Cell 96:245 254.

Wong SK, Lim YY, Abdullah NR, Nordin FJ (2011a). Assessment of antiproliferative and antiplasmodial activities of five selected Apocynaceae species. BMC Complementary and Alternative Medicine 11:3.

Wong SK, Lim YY, Abdullah NR, Nordin FJ (2011b). Antiproliferative and phytochemical analyses of leaf extracts of ten Apocynaceae species. Pharmacognosy Research 3(2):100-106.

Yaacob NS, Hamzah N, Nik Mohamed Kamal NN, Zainal Abidin SA, Lai CS, Navaratnam V, Norazmi MN (2010). Anticancer activity of a subfraction of dichloromethane extract of Strobilanthes crispus on human breast and prostate cancer cells in vitro. BMC Complementary and Alternative Medicine 10:42.

Yang LQ, Fang DC, Wang RQ, Yang SM (2004). Effect of NF-kappaB, survivin, Bcl-2 and Caspase 3 on apoptosis of gastric cancer cells induced by tumor necrosis factor related apoptosis inducing ligand. World $\mathrm{J}$ Gastroenterology 10:22-25.

Zhu W, Zhang J-S, Young CYF (2001). Silymarin inhibits function of the androgen receptor by reducing nuclear localization of the receptor in the human prostate cancer cell line LNCaP. Carcinogenesis 22:1399-1403. 